University of Louisville

ThinkIR: The University of Louisville's Institutional Repository

Electronic Theses and Dissertations

$1-1927$

\title{
The influence of a high and low vitamin content in nutrition.
}

Ruth Lovelace

University of Louisville

Follow this and additional works at: https://ir.library.louisville.edu/etd

\section{Recommended Citation}

Lovelace, Ruth, "The influence of a high and low vitamin content in nutrition." (1927). Electronic Theses and Dissertations. Paper 858.

https://doi.org/10.18297/etd/858

This Master's Thesis is brought to you for free and open access by ThinkIR: The University of Louisville's Institutional Repository. It has been accepted for inclusion in Electronic Theses and Dissertations by an authorized administrator of ThinkIR: The University of Louisville's Institutional Repository. This title appears here courtesy of the author, who has retained all other copyrights. For more information, please contact thinkir@louisville.edu. 


\title{
THIVERSTYY OF LOTSYIIIS
}

a

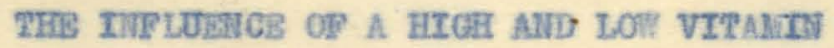

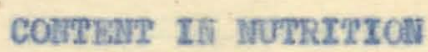

\begin{abstract}
A Disisertation
Subratted to the Faculty

of the Graduate Sahool of the College of Liboral Arts

In Pnrtial Pulfillment of the

Requirements for the Degreo

of Llastor of Selence
\end{abstract}

Departmont of Chemistry

Dy

RUTH LOVBTACE

1927 


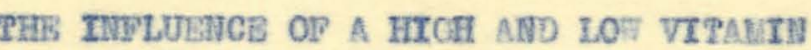

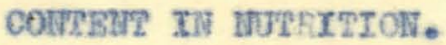


InTrODJCEzON. 
In the buiks of experiments on enimal feeding the Albino Rat has served as the experimental animal. It has been proved that any diet which brings about satisfactory growth in white rats will also cause a young child to grow satisfactorily. Thorefore, much attention is given to the breoding of suoh rats for experinontal and golentiflc use.

In the earliser gtagos of experimentel woric it was found that a diet which contained surpicient proteln material and which yielded the proper number of ealories beanse of the sat, sugar, and starch present, was a satisfactory diot.

Latier lnvestigntions shmod that animel.s fed on diots which correspondad in every reapeot to the diet nontioned above, ald not thrive. The addition of certain minoral salts to the difer sorvod to eliminate the trouble. This showed that a dist, in order to be adequate, must contain cortain minoral salte in definfte qunntitios. Then the scientists began an intensive structy of the protoin substences from difforent sourees, they found that they did not all possess the same food velue. Sone protelns produced normal growth and some did not, Due to this fect, to-day we divide the protelns into three groups- Complete; Partially oomplete; end Inoonplate Protolns. If en animal is fed on a diot, of which the protein quota is made from the incomplete protelns, it will not grow normelly. A great nany of our foods that nature givos us in abundanoe have presont in them incomplete protelns. 
Dp to this time nothing but the solld constituents of the diet, thet is, the fats, carbohydreten and protein had soen enphasized. Howover, the importance of the liquid side of the diet came gradus 11 y to be opprecinted. Hater ves quile cssential for $11 f 0$ and is of msteriel essidatence in the body processus as digostion, absorption, and excrotion.

Through a sertes of yoars and by neans of many carefuliy controlled experiments the scientirle oplnion was to the exfect thet a diet was adoçute if it consisted of the proper mount and zand of earbohydrate, protein, fats, mineral, and water.

It did not take long, howevor, for experimenters to find out that diebs made up scoorcing to the ebove stendard ald not alvays yiela setisfectory rosults. Cutte a bit of worle was done in these yours end thore vere times when one scien'sist co vid not vorify the results of enother sciontist. Pinally, In recent years and affor much regontch, it wing definitoly dectadod that norrel grouth could not be obtained on the above mentioned diet. In orier that an enturel shonld shor nomel growth sud be free fron certain diom orders, 1ts diet mut contrin cortain sulsst noes which are oallod accessory food su'stences or vitbutine.

To-dry a diot in order to bo adequate for grovth mut contaln the following Pactore: 


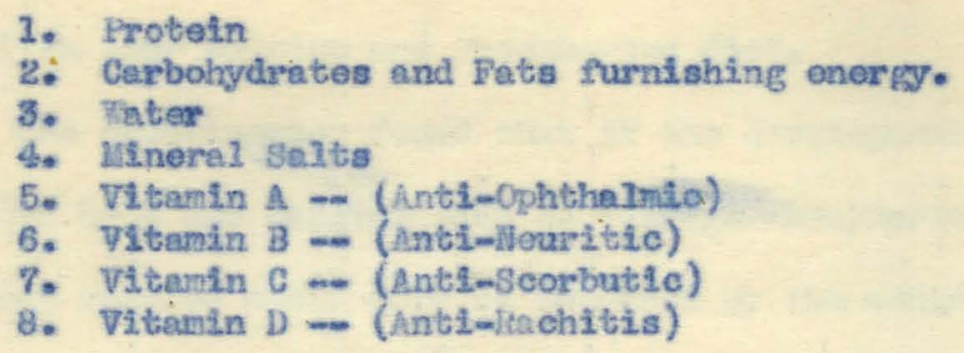

The ash constituents have long beon recognized as playing an Importbant part in the grourth of young animals, and of these, the elemonta most Iikely to be deficient are Calcium, Fhosphorous, and Iron. Young sninals are generally born with a reserve store of iron and when this reaerve supply hes been used the iron in the body will be found localized in the blood. A defialency of iron becomes more noticeable in the bloud than in other tisanes, thorefore, growith may not cease but the aniral or young child may grow anenje. The Galeivan is localized in the bones and over $99 \%$ of the Calcium is found there. An inadaguste suppiy or Calcium in the food during grouth rotarcis the dovolopenent and celolfication of the bones.

Bone development may also be interferred with by the inadequacy of the thosphorous supply. Severel investigators in studying the effect of the diet upon the growth of the bone, have found that the bones formod in young animals kopt on a diet poor in phoaphorour and Caleitur are apt to be soft, spongy and weels. This moy be preventod by the addition of Caleiun Phosphate to the food or Cod Liver 011. There has been sone argunent as to the value of Cod 
Liver 01.1 in poor Gelestun and Fhosphoroug diơt.

One exparimenter foumd that is the dovolopmont of bones

Is rotarded by a low Calolus dît of strarage Phosphorous content. that normal results could only be obletnod by the addation of Calctur salts to the food and not by feoding Cot Liver ofl. Too mach confldence hos been put in the value of the Anti-Rachitie Vitamin and not onough cure has beon telken in providing a 2tbaral supply of Celeturu ene Thosphorous during the portod of grouth and development.

Other Inrostigators state that in the presenco of Calcium

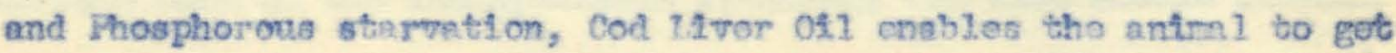

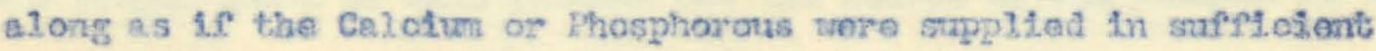
gunntities in the diet. Cod IIver ori not onity aots as a regulator of Calclum end Fhosphorous motabolitm but a.1so permats the or-

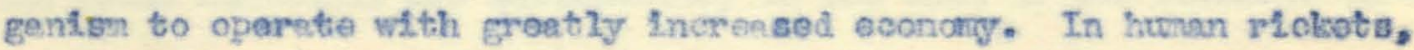
the organism has logt the powor to e.sstmil tete and hold the 13 mo an 1te. Cod Liver orl furnishos somothing to the body which onobles it to assimtlate and hold the Ifwe selts. Goll Ifvor ofl nakes tho metabolite processes of the body, in respect to Caloiun and Fhosphorous more erflefont. That cod Liver osl acconplishes in zicisets is nothing more than the rastoration of it pover to rake a successful adaptation to a faulty diat and a fauity environtientel condstlon (room light).

The vitamins occur only in certein foods and are there in 
only mall amounts. The conoentration of these vitamins is so low in foods that they have never boen obtained in large enough anounts for solentists to doternine thefr escact charaoter. Thoy have found, hownever, that they are Indtupenseblo to the difet. A young animal os young ohl1d will not be well nourishod unless it gots the proper amount. of tho vitanins, two, Vitanin A. and VItesin B. are the gronth promoting substancos. If the animel recelvos the proper amount of protein, earbohyairates, fat, minerals, Vitamin C. and Vitamin D and VAtanin A and Vitanin B are abount or in insufpioient quantities, normal grouth is inpossible, of courso, each individual food cannot contain each of the indispensable vitewins. The ditot should contain the proper guote of each vitamin but the source of the vitamin is animportant. We do not exclade such strplo foode as white rice, potatoos, and white bread from our diet beceuse of their defioloney in Vitanin A. The foods nentioned are satisfactory in the diet if the vitamine como from other sources.

Selentists have carried out experinents on various vitamins and Investigated various foode to to thoir vitamin content and conelderod the stucy of vitanin A quite important. Glosely roletod to Vitanin $\mathrm{A}$ is Vitenin $\mathrm{D}$, the Anti-Rachitie Vitamin. Milik, man's bost food, conteins each of the essontiel vitanins. The nilk fat or buctor contains Vitarin A.

Rats which heve ecasod or failod to grou on natural "protoinfree milk" diets in which lard fturnished the fat componont, grouth was resumed whon butiter-fat was aubstituted for lard. So butter-fat contains substances necessary for growth as well es maintonance. 
Reoent study of the satil-seorbutie velue of com's nillk shows that it is lees valuable thon many ras frults and vogobablos. It takes large quantitioe of nillk to prevent ecurvy in gainet-pigs and to produce an iffproved rate of growth, which are rondtly socurred by very mall quartitles of many driod groen vegetables.

If fow years ago experimenters becumo interested in whother or not a lack or Insuffletency of tho Anti-Scorbutie VItemin in tho diet would have any influence on the sornation and malntenence of tooth in aninals. Some of the carllost authors have looltod upon the tooth as a flxed part of the body, in other worde a doad aubstance, undergoing no ohange during the disferent pathologiosl prooossed in the genorel organlan. There was no reason to bellere that the tooth should bo any exception from other psurts of tho organian vibore an active metabolism is going on, so stuales were aade to see whether chery found any ohemicel chenges going on in the tooth during metabolie disturbences, es for Instance in scurvy.

Bxperiments ware triod on guinea-pigs and there ress found In soorbutio guineampigs a doercese in Calcium and Increase in tiage nesiun oontent. This subetitution of Caletran by Irganosiun is naturea attoryt to lcoep up the anounts of salts in the teeth when she is in need of the Calcfirr. This is a pathologtenl progess and As clnssed uncer the term Osteomalsois. The hith lagnosium content may also account for the very bribtle condiction of the teoth in acorbutblem fed guinea-pigs. Thus we see that a diet dericient in the Anti-Scorbutic 
Vitamin is able to produce both histologioel and chomical ohanges in both the teeth and bones of animels.

The minorel moteboliom, as affecting the concentrutions of Fhosphorous and of Calcium in the blool; the Anti-Reohltis $V_{\text {stamin }}$ now inown to exist in Cod Iiver 011, Ogg yolk, whole milk end othor foode; and the viltra-v\$olet rays of direet sunlight are all important Pactors in cxusation end provention of rickets. Exporimentally rickots can be produead by a diot of fauliy nineral content, but asually only Whore there is a deftciency of the regilating factors- Anti-lechitie Vitanin and vitra-violet light.

Our present view is thet rialcots is a natter of nuttitional

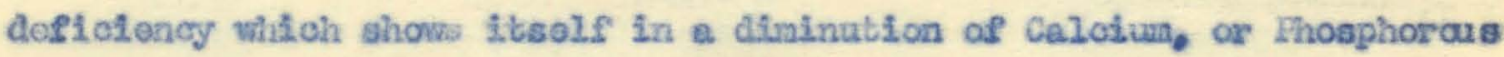
or both in blood sebru, and ean be prevrated by naintenance of normel Calolun and Phosphorous content of blood oprun whother this be acoonplishod by direct attiention to the motebolian of Calofiun and Ihosphorous es such, or through the aid of the Anithrachitio Vitamin or Ultreviolet rayse.

Dnough experimentel worls hes been done to prove that vitanins are guite gssential in the dist. Yet there is sone doubt, howevar, as to the amownt that is necessary in the diet to produce the bost results. - The purpose of the reacerch undertalcen as presented in this thesis is to show the effeots of high and low vitamin contents in the diot as shom by experinonts with white rats. 
EXPGRT:BivaL.

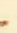


The rats used in this experinont were one litter of AIbino Rats, contalning elovon individuals. The rats were about twenty-Plve days old when thoy vere separated from thoir mother.

The rate were wolghed and placed in individual santtery cages when four weeks old. Thoy were given all the sood of their respective diets that they could ent.

The rate wore all subjected to the same conditions of environnent and temporature. Their velghts were taken weokly and all changes in appenrance wore noted.

The litter of eleven subjects was divided into three groups of three, four, and four, and were fed on the following diete:

\section{GROUP ONE}

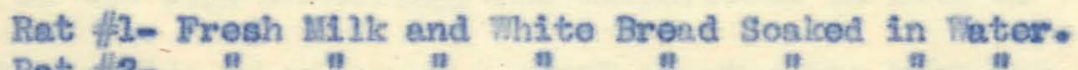

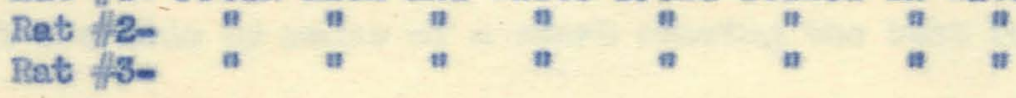

GROUP TIO

Rat $/ 4$ - Fresh Vilk, Ice Crean and white Bread.

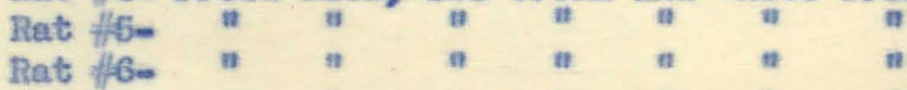

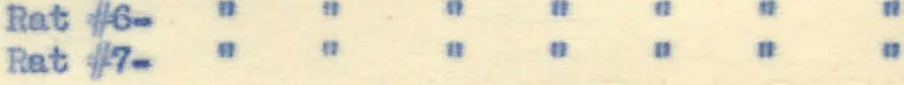

\section{GROUP THERE}

Rat $\# 8$ - Ice Cream, White Broad Soeised in Whter. Rat $19-$ Rat H10-" Rat 갤11- "

a)

a

n

$\begin{array}{lll}a & a & n \\ n & a & a\end{array}$


The rats of Group II showed the best results. The rats fod on bread and milik and bread and ice cream showed a steady incroase but not os rapid gein in wright as the ones fed on breed, mill, and foe crean. The rats In Group II wore perfootly hoalthy and their fur was white and soft.

The rats of Group III woro not as active 28 of the othor two groups--lack of protein (easeln) due to lack of milk in their diets.

The welghts of all rats fod on the sane diet are given on the page following, and comparisona in rate of growth are made by means of a chert showing the best rat fron ach group. 


\begin{tabular}{|c|c|c|c|c|c|}
\hline & & $\begin{array}{l}\text { Rat fir } \\
\text { Nale }\end{array}$ & $\begin{array}{l}\text { Rat } \frac{112}{2} \\
\text { Fornale }\end{array}$ & $\begin{array}{l}\text { Rat } 3 \\
\text { Male }\end{array}$ & \\
\hline Sopt. & 15 & 34.4 gns. & 23.6 gns. & $30.3 \mathrm{gma}$. & \\
\hline a & 22 & 46.4 & 35.6 & 45.5 & \\
\hline$n$ & 29 & 66.9 & 57.2 & 69.5 & \\
\hline Ooţ. - & -6 & 91.9 & 72.8 & 91.6 & \\
\hline $\mathbf{a}$ & 23 & 130.0 & 91.0 & 114.0 & \\
\hline 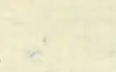 & & & GroUP TIO & XXEЕ IEMTA & \\
\hline . & & $\begin{array}{l}\text { Ret 개 } 4 \\
\text { Pemale }\end{array}$ & $\begin{array}{l}\text { Rat il } 5 \\
\text { Ralo }\end{array}$ & $\begin{array}{l}\text { Rat th } \\
\text { Hale }\end{array}$ & $\begin{array}{l}\text { Rat ill } 7 \\
\text { liale }\end{array}$ \\
\hline Sept. & 25 & 26.9 gna. & 34.9 gens. & 35.9 gुns. & 31.2 gins. \\
\hline$n$ & 22 & 43.7 & 48.1 & 50.0 & 45.4 \\
\hline * & 29 & 62.2 & 60.0 & 78.7 & 70.0 \\
\hline Oet. & 6 & 85.2 & 82.3 & 100.9 & 108.5 \\
\hline a & 13 & 104.5 & 105.0 & 130.0 & 330.0 \\
\hline & $=$ & & GROUP THRE & (EXPRI) & 1.) \\
\hline & & $\begin{array}{l}\text { Rat } 8 \\
\text { Persalo }\end{array}$ & Rat 19 & $\begin{array}{l}\text { Rat } 10 \\
\text { lalo }\end{array}$ & Rat 411 \\
\hline Sept. & 15 & 26.9 gुns. & 32.2 g:s & 35.0 grns. & 34.7 gns. \\
\hline a & 22 & 45.2 & & 51.3 & \\
\hline "t & 29 & 60.5 & & 69.7 & \\
\hline Oot. & 6 & 71.2 & & 87.1 & \\
\hline$n$ & 13 & 82.0 & & 202.0 & \\
\hline
\end{tabular}

Rats $\| 19$ and 411 got out of ceges and could not be enught. 

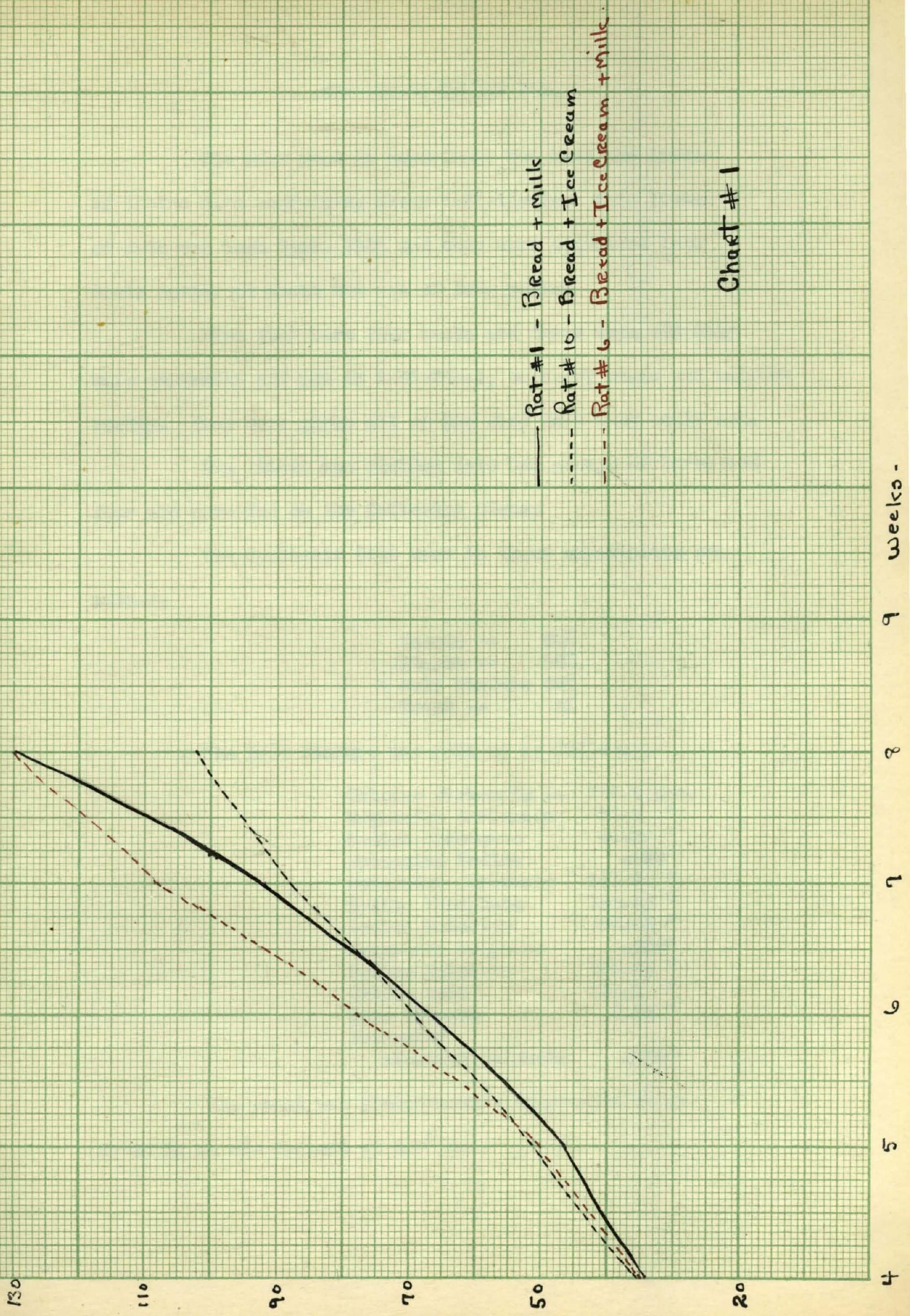
The rats used in exporiment two wore one litter of Albino Rats conteining sevon inat ridue 1s. This litter of rats was born Sopt. 10th and thøy wero seperatod from their mother at about the age of four: reeks.

When they wore four woekcs and throe days old thoy wore separated and put in individuel, senttary cages and weighod weelely. They wore given all of the food that they could eat.

The litter was dividod into two groups of three and four and were fed on the following diets:

The Synthetic Diet used in these experiments contained:

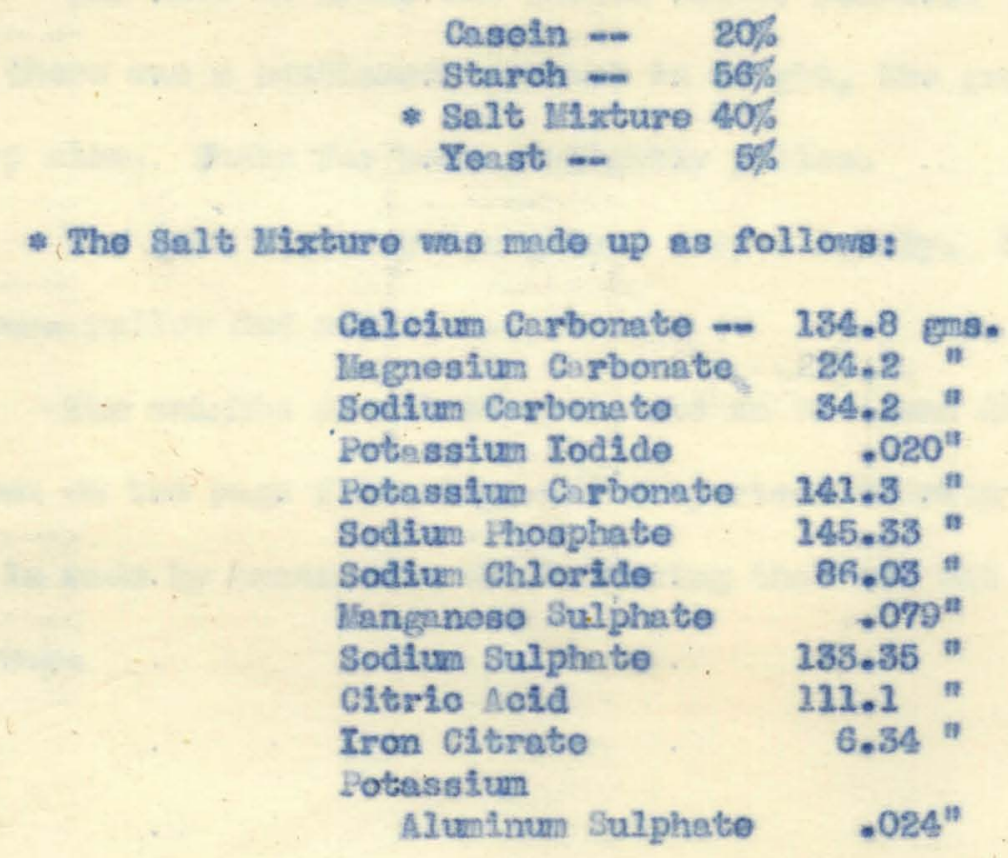

The yeast was Nleischmann's Compressed Yeast dried In an air curront at $100^{\circ} \mathrm{C}$. 


\section{GROUP OME}

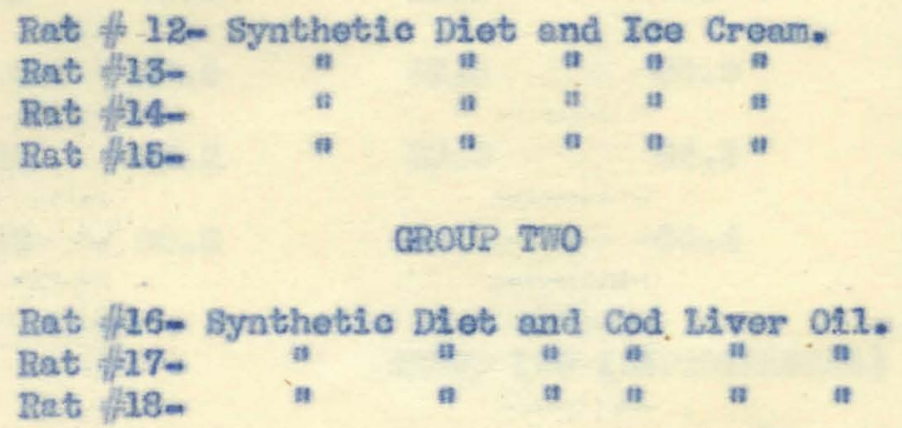

The rats in Group One showed better resulta. A1though there was a contimued incronse in weight, the growth was very slow. Their fur became slightly yellow.

The rats in Group Two gained vory slightly. Their fur bocame yellow and stifs.

The weichts of all the rets fed on the sume dilets are given on the pege following, and comperison in rate of growth is made by means of a chart shoring the best rat from each group. 
GROUP OHB (EXPBIIISUTAL)

$\begin{array}{llll}\text { Rat } H 12 & \text { Rat } \# 13 & \text { Rat \#14 Mat \# } 15 \\ \text { Iale } & \text { Fonalo } & \text { Female } & \text { Hale }\end{array}$

oet. 942.3 gas. 36.3 gess. 36.5 gns. 36.0 gas.

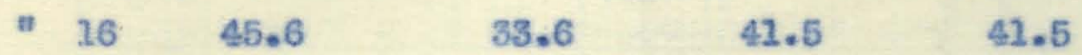

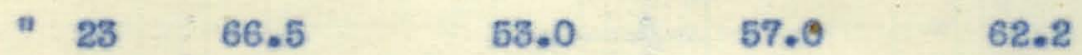

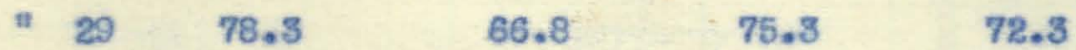

$\begin{array}{lllll}\text { Nov. } 5 & 86.6 & 68.3 & 86.9 & 79.9\end{array}$

$\begin{array}{lllll}* 15 & 82.2 & 69.0 & 84.3 & 79.5\end{array}$

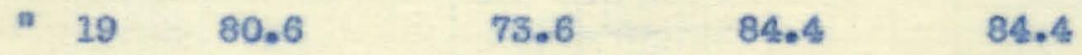

\section{GROUP TIO (WXPERIINTAL)}

\begin{tabular}{|c|c|c|c|}
\hline & $\begin{array}{l}\text { Rat H16 } \\
\text { Male }\end{array}$ & $\begin{array}{l}\text { Rat 규 } 17 \\
\text { Nale }\end{array}$ & $\begin{array}{l}\text { Rat } 1 / 18 \\
\text { Fennle }\end{array}$ \\
\hline Dot. 9 & $41.0 \mathrm{gms}$ & $40.0 \mathrm{gms}$ & 40.058. \\
\hline${ }^{n} 26$ & 31.1 & 30.1 & 28.1 \\
\hline tod. & Dob. 21 & 0ot. 20 & Oot. 18 \\
\hline
\end{tabular}

Three rats wore taken fron the 21 tter born sept. 28th and were fod the samo diet as Group Two.

\begin{tabular}{|c|c|c|c|c|}
\hline & . & $\begin{array}{l}\text { Reat } t 19 \\
\text { Feme } 10\end{array}$ & $\begin{array}{l}\text { Rat } 4 / 20 \\
\text { Nale }\end{array}$ & $\begin{array}{l}\text { Rat Hat } \\
\text { NoIe }\end{array}$ \\
\hline oat. & 21 . & 21.5 gns. & 22.5 gns. & 22.9 gms. \\
\hline n & 29 & 23.6 & 24.5 & 24.8 \\
\hline Wov. & 5 & 23.4 & 21.8 & 20.4 \\
\hline a & 23 & 24.0 & 22.5 & 21.0 \\
\hline " & 19 & 42.1 & & 33.6 \\
\hline Died & & Nov. 20 & IIov. 15 & Nlov. 19 \\
\hline
\end{tabular}


The rets used in Esperimont Throe ware three 11tters of Albino Rats consisting of six, six and ef ght youthg. The rats were born Sopt. 28th, Oot. 4th, and Oat. 5th.

At the age of three woelcs the young were separnted from their mother.

The rats were plsced in individunl, eanitary enges at the age of four veelcs. They wore subjeoted to the anme conditions of environnent and temperature. They were fed the same anount of their diet and their weights vore taken weekly.

The three litters of rats were divided into 'five groups of four each and wore fed on the following disets:

\section{Gritous}

Rat H22- Nazole 011 and Synthetic Diet (Outilined in Bxpt. Two)

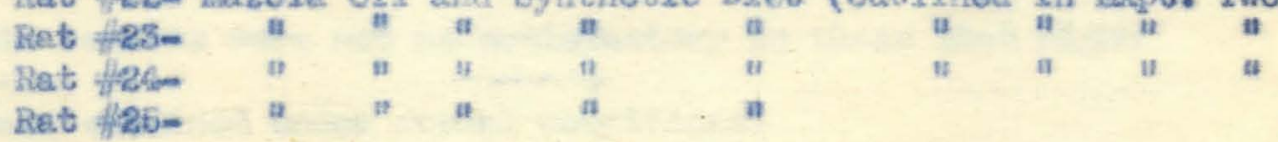

\section{Gour Ino}

Eat $426-$ Cod Lifver O\{I, Symthotie Dist, and Ice Cream. Rat $=27-$ Pat thesm Rat He9-" 
Gete THESB

Rat 1 s0m Inala 013, Synthetic Diet, Ice Crear.

Rat 1.31-

Pat Nk32-

Riat Hos-

a

it

at

\section{GROUP IOUR}

Rat 734 - Ice Creara, Carrotis, Synthebic Diet. Rat $=185$ Rat $36-3$ Rat if $37 \mathrm{~m}$.

\section{Grode BIVE}

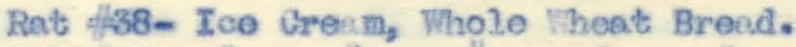
Rat 39 Rat 40 m Rat 41 - .

$\begin{array}{llll}\text { in } & \text { un } & \text { un } \\ \text { a } & n & \text { u } & \text { n } \\ \text { if } & \text { u } & \text { u } & \text { ut }\end{array}$

Due to difficuity in rainbaining a consbant temperature the resulss wore not as setiafaetory as those that night hevo been obtained under normal conditions. The weights of ell rats fed on the same diets are givon on the pege following end comperisons in rate of growth are made by means of a chart showing best ret fron esch group. 


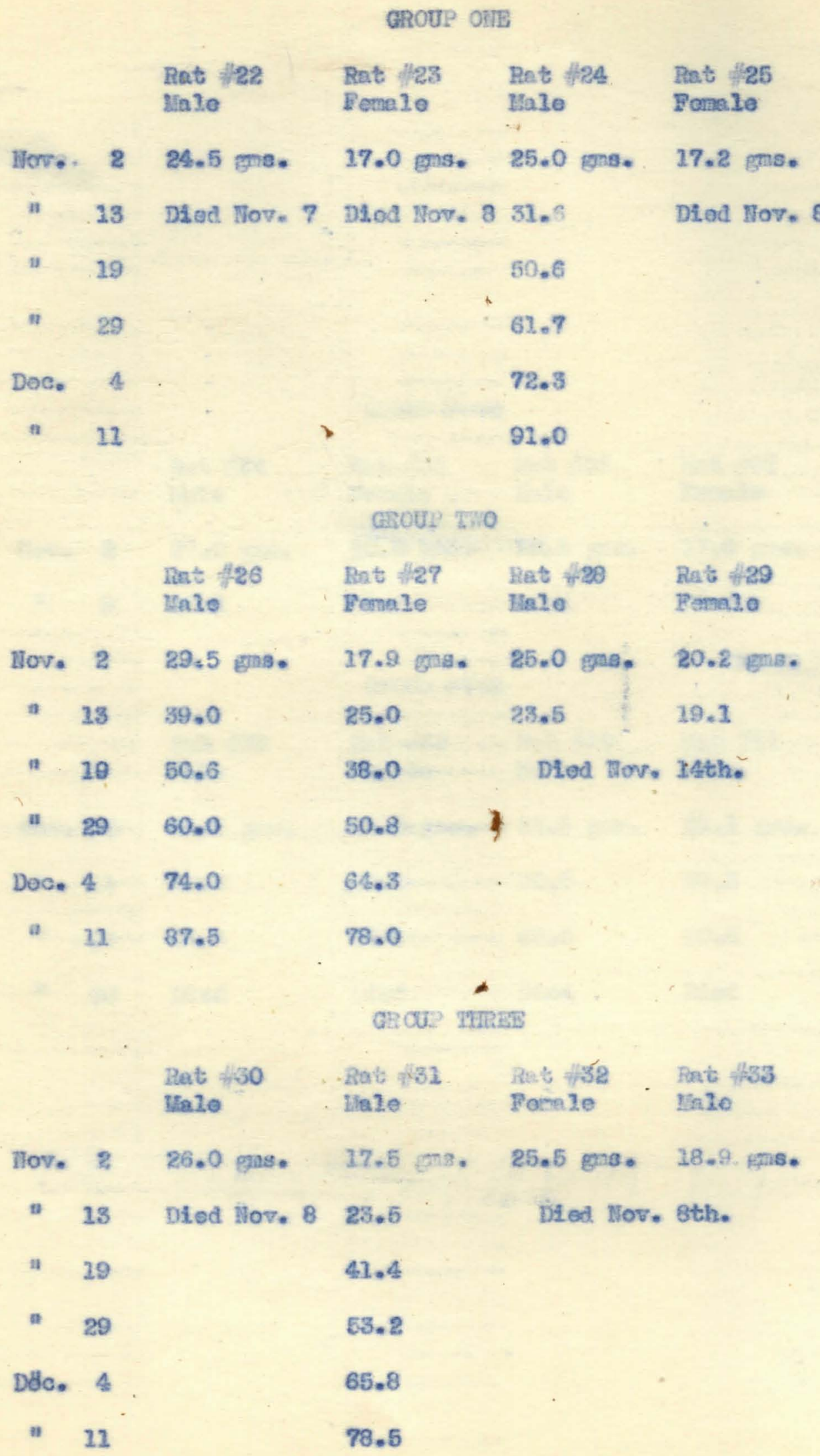




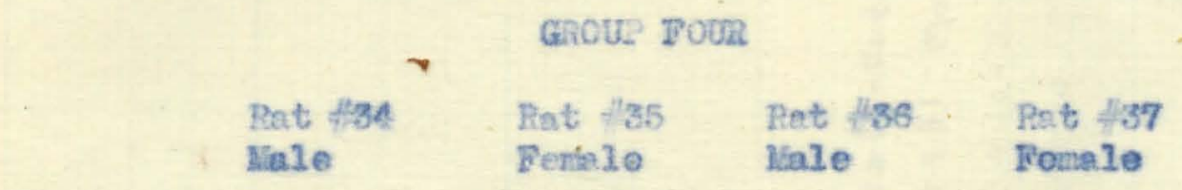

Nov. 227.5 gns, 20.0 gns. 29.5 gns. 27.8 gms.

" 9 Died Died Died

\section{GPOTP PrTE}

\begin{tabular}{|c|c|c|c|}
\hline Pat lize & Plat $/ 39$ & Bat tho & Rat t, 19 \\
\hline lele & Jerre le & $\ln 10$ & Male \\
\hline
\end{tabular}

IIov. 232.5 gns. 24.0 gms. $32.8 \mathrm{gmin} 25.1$ gns.

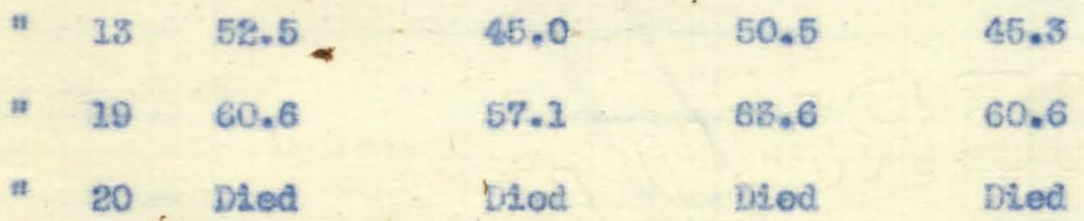



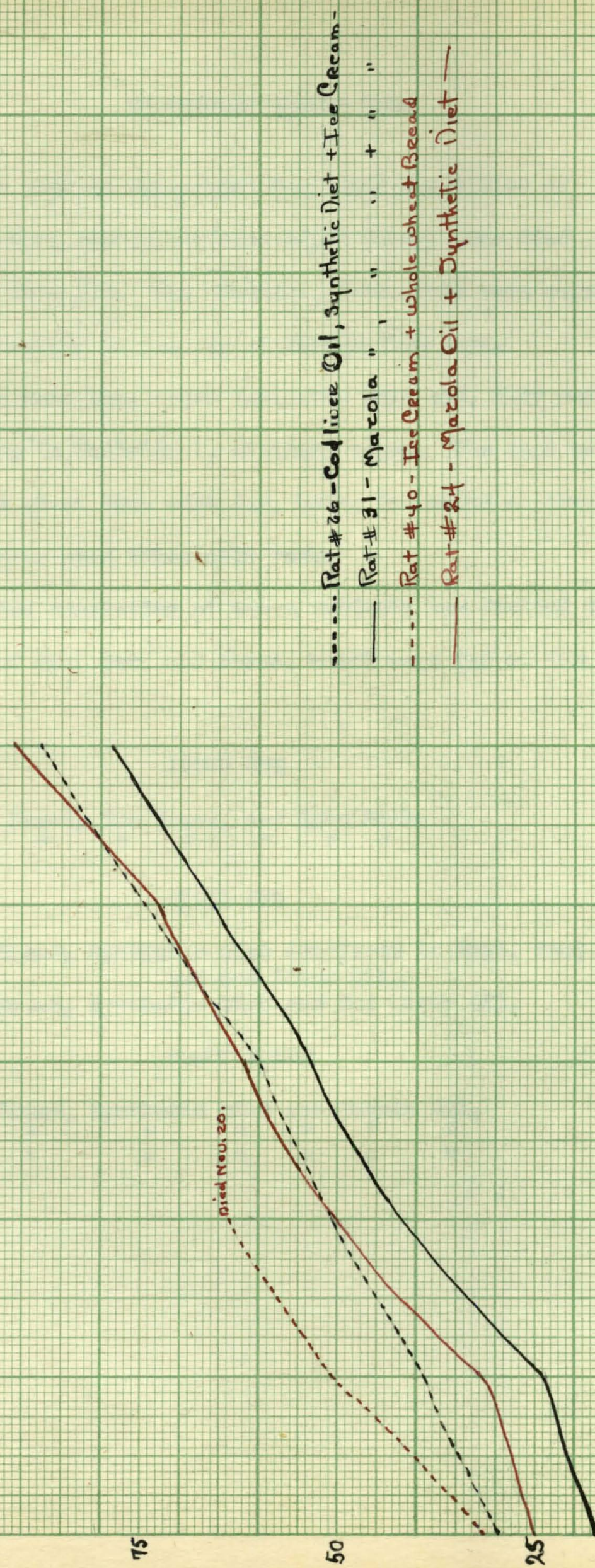
The rate ueed in Foperinent Four ware one 21.tter of Albino rats born Nov. $25 b h$ containing of ght yeurg. One died when about seven days ofd. The remalning sowen rets were separated fron thetr mother not the age of thimby-esta dayto.

When the rats were about fortymone decge old, they were woighed and pleced in individual, sanitary onges. The seme am mount of food mas gtwon then exch dey, beting inaressed so thoy grow. Thoir weights were teken each moeks.

The 1tfber consi gting of soven eubjects mes divided into throe groups of two, two, and three, which were fect on tho . following alebs:

\section{EROTP ONE}

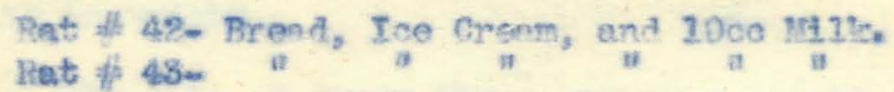

\section{Grots ThO}

Rat \#\#4- Bread, Synthetic Diet (Outlinod in Expt. Two) and Cod IIJar OLI.

Rat Hitb- Bread, Synthetic Diet and Cod Liver 012.

\section{GOUP THPEE}

kat 146 - Bread, Synthotic Diet and llazole 012. 
The rats on the rogular di.et showed a nomel rate of growth and a steady Inerease in weight.

The rats in Group tho showed a slight incrosso in weight. At the end of the second weolk one rat died. Their fur did not remain white and soft but become dnele and bristly. After tro wooks, a small amount of 150 cream was added to the difot and the ratg became healthier and thelr fur beceme whtte and seft argain. The feeding of the regular di.et ascribed to Group Two with the addition of too eroom was continued. The rata showed a steady Increase in veight.

The rats of Group Throe showed a sli.ght snd steudy Increase in weight with the excoption of the fifth week. Thoy did not look healthy, although thoy ware wory active and spry. Thois fur instend of being white and soft turned yellow and stiff and stringy. This was possibly duo to the lack of vitenins and Calclum.

The weights of all rats fed on the same dipts are given on the page following, and comparisons in the rate of grovth are madle by moans of a chart showing the best rat from each group. 


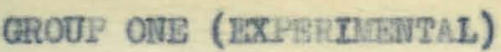

\begin{tabular}{|c|c|c|c|}
\hline & & $\begin{array}{l}\text { Rat \# } 42 \\
\text { Rale }\end{array}$ & $\begin{array}{l}\text { Rat } \frac{1}{73} \\
\text { Nale }\end{array}$ \\
\hline Jan. & 5 & $46.5 \mathrm{gms.}$ & 49.5 gुण 3. \\
\hline$u$ & 10 & 61.0 & 74.9 \\
\hline * & 18 & 83.7 & 92.8 \\
\hline 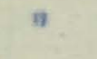 & 28 & 96.0 & 203.5 \\
\hline Fob. & 4 & 107.5 & 220.5 \\
\hline 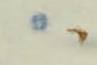 & 25 & 207.5 & 120.5 \\
\hline * & 18 & 222.5 & 221.5 \\
\hline & & & 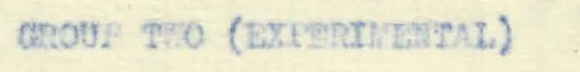 \\
\hline & & $\begin{array}{l}\text { Detc t } 44 \\
\text { Bemale }\end{array}$ & $\begin{array}{l}\text { Rat } 45 \\
\text { Pomale }\end{array}$ \\
\hline Jan. & 5 & A. .5 Bns. & 44.5 gถร. \\
\hline a & 10 & 57.5 & 57.5 \\
\hline$n$ & 18 & 71.7 & Died Jen. 17th \\
\hline a & 28 & 88.5 & \\
\hline
\end{tabular}

Pob. 496.5

14 100,0、

" $\quad 28 \quad 305.5$

Grove TERE: (MXPNINSETAL)

Rat \# 46 . Rat 197 Rat 48

Vinlo No.20 Fennio

Jan. 5 44.5 gans. 52.0 gns. $37.0 \mathrm{gm}$.

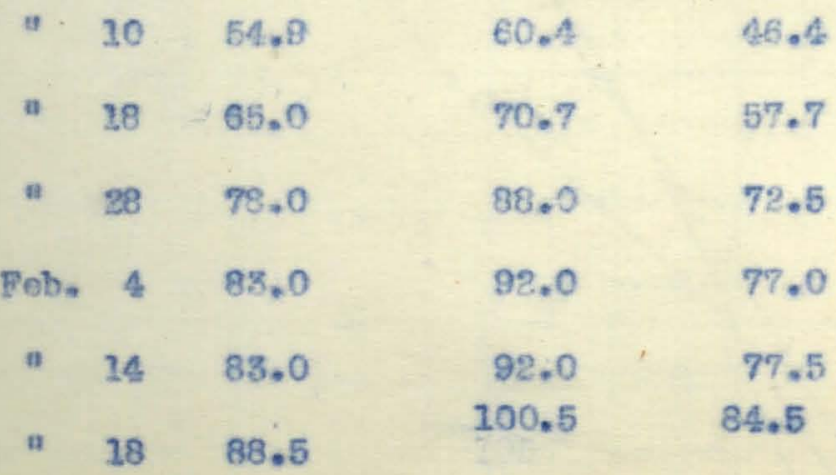




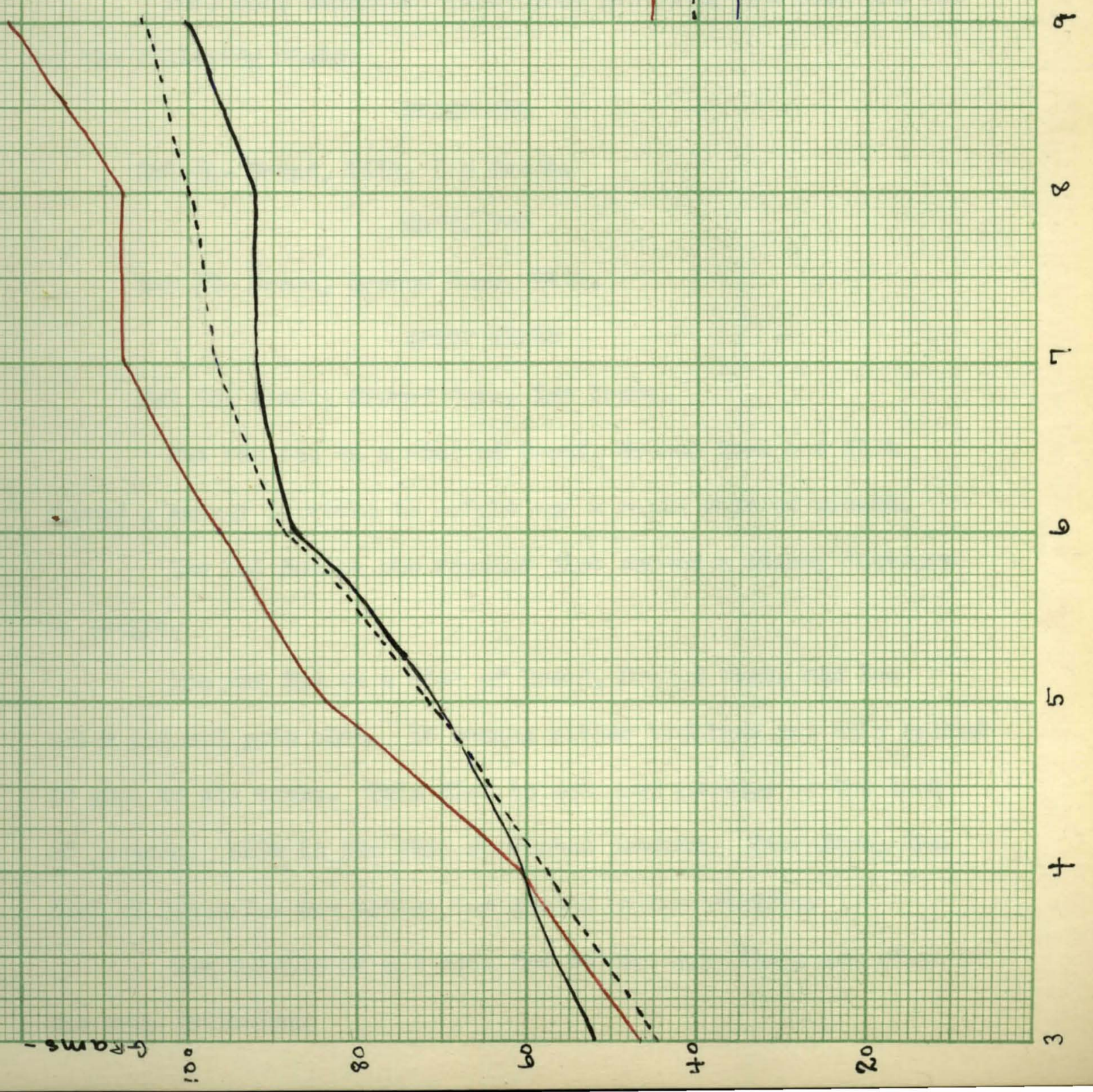




\section{EXPIRIIIAT NUSBER FIVE.}

The rats used in this exporiment were three male rats about ton woels old.

Thoy wero woighad and placed in Individual sant.tary cages. Thoy were suhjected to the s mo conditlons of temperature and onvironiont.

Thoy were wei.ghed weokly and given as ruch of thoir diots as they could eat.

They wore separated into three groups of ono ench and fod on tho following dtets:

\section{GROUP OHE}

Rat th- Bread, wt we, Ice Crean.

GROMP THO

Rat As- Broad, Ground Corn, 15,11k.

\section{GROUP TRT:BS}

Rat $\mathrm{AC}-$ Bread, Ground Corn, Ice Gronen.

The rat fed on a diet of Bread, Ground Corn and $\mathrm{kilk}$ Showed a steady. Increese in woight and a rapid rote of growth.

The rat fed on the regular diet shovod a atendy incroase is meight.

The rat fed on a diet of Broad, fround Corn, and Ico Gro in did not gain much. It becane rather 13 stless and only gainod 19 gls. In gis weelcs. This dilet is not good because of the lack of protein. vilk in the diot furnishes proteln. Therefore, the di.et of Group Iro wets better and showod better results.

The weights of all rats fed on the same diets aro givon on the page following: 


\section{GROUP OVE (COTPROL)}

\section{Rat $\|$ A}

Nale

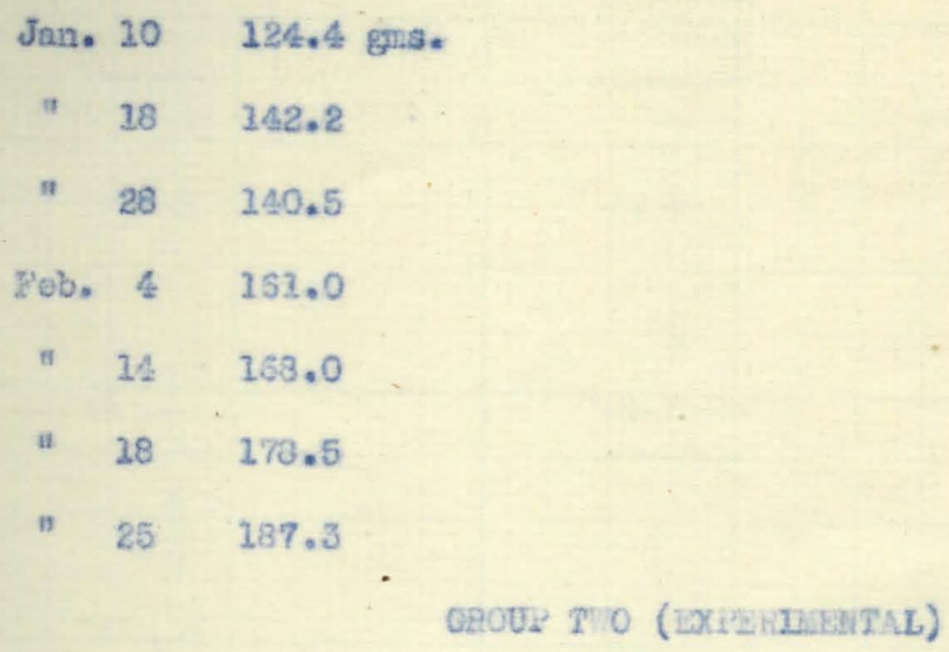

Rat $B$

Haie

$\begin{array}{ccc}\text { Jan. } & 10 & 167.9 \\ " & 18 & 181.0 \\ \text { " } & 28 & 128.5 \\ \text { Fob. } 4 & 201.5 \\ " & 14 & 207.0 \\ \text { " } & 18 & 207.0 \\ \text { " } & 25 & 212.0\end{array}$

GROUL THRES (BXPERTMIUTAL)

Rat $\|$ HC

Siaje

Jen. 10170.9 gns.

$\begin{array}{lrr}\text { " } & 28 & 265.7 \\ n & .28 & 173.5\end{array}$

Fo. 4.160 .5

$\Rightarrow \quad 24 \quad 17.0$

" $18 \quad 180.0$

* $25 \quad 189.5$ 


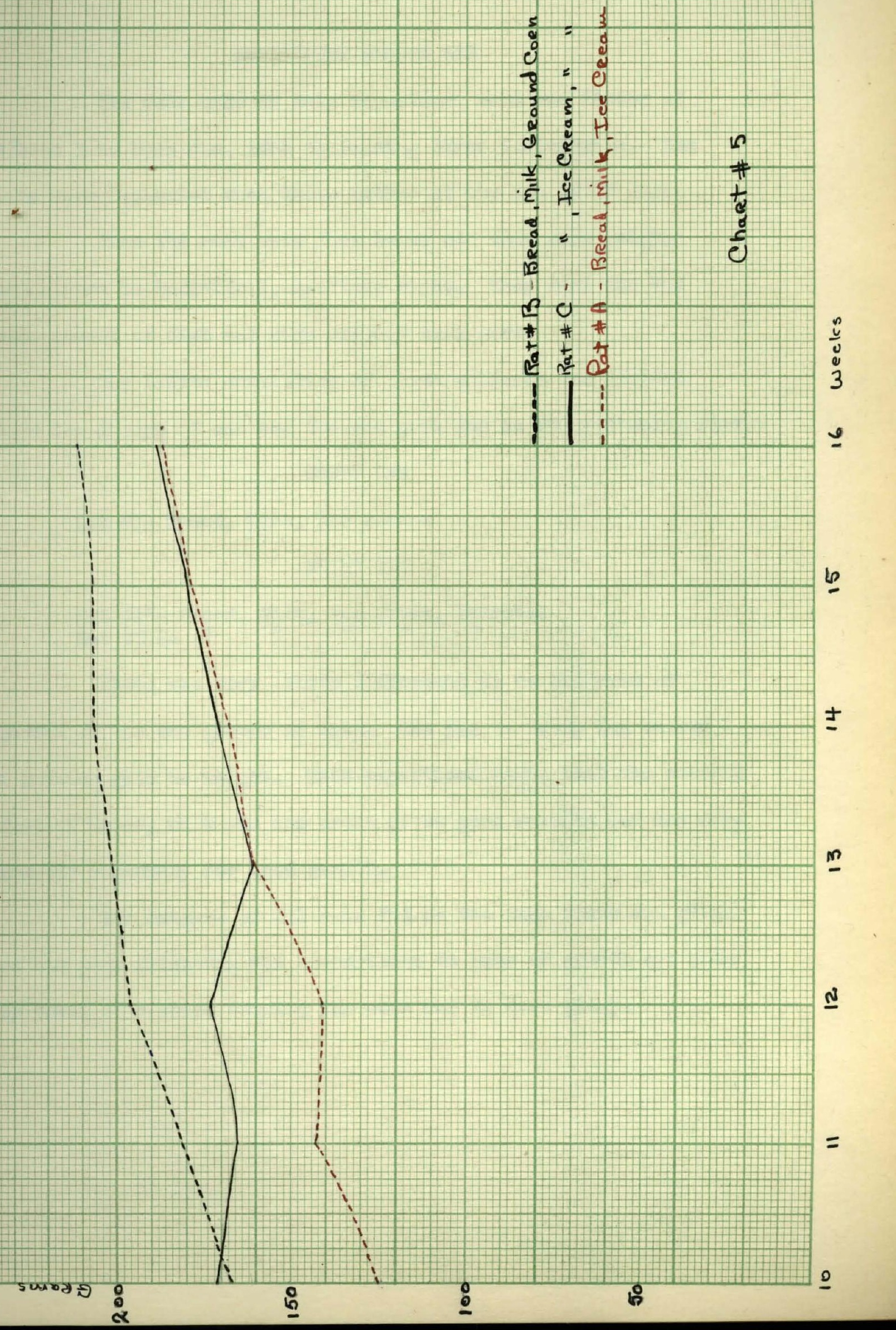




\section{EXPRI BUR NUIBB? SIX}

The rats used in this exporiment were one littor of Albino Rats born Jan. 26th conteining thrae individuals. Tho $r_{\text {the }}$ vero soparated from tholr mothor at the age of 23 days.

When the rata were four waoks old thoy were uretghed and pInoed in Incivitual, sanitary cages. They wore fod tho same anourt of diet and were weighed each veek.

The littor conatisting of throo aubyeots ims divided Anto two groups of one and two and wore fed on the following diets:

$$
\text { Gare ars }
$$

Ret \#I- Brond, Milk, Ieo croate.

\section{Grots Tio}

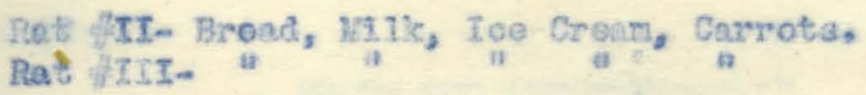

Phere ras very littile differanon as to the rete of growth of tho two groupe of ratis. Ono rat in Groug Two showed a grostrer grin in wreight. Phis experimont shows that the control díet of breed, nilk and ice eream gives good results and has oubstancos neoassary for good grorth.

The welghts of all rats fed on the same diets are given on the page following and comparisons in rate of growth are made by moans of a chart showing tho beat rat in asch group. 


\section{GROT: OIS (COMTROL)}

Ret $f 5$

Fonale

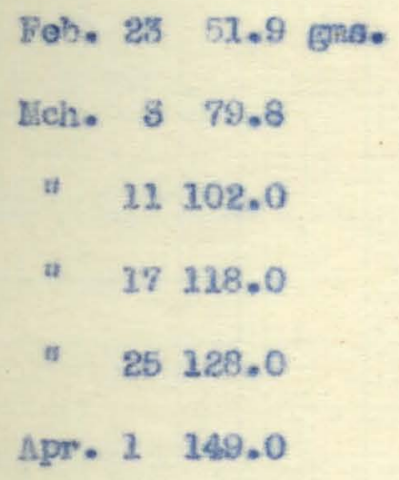

Appe. 1233.0

362.0 

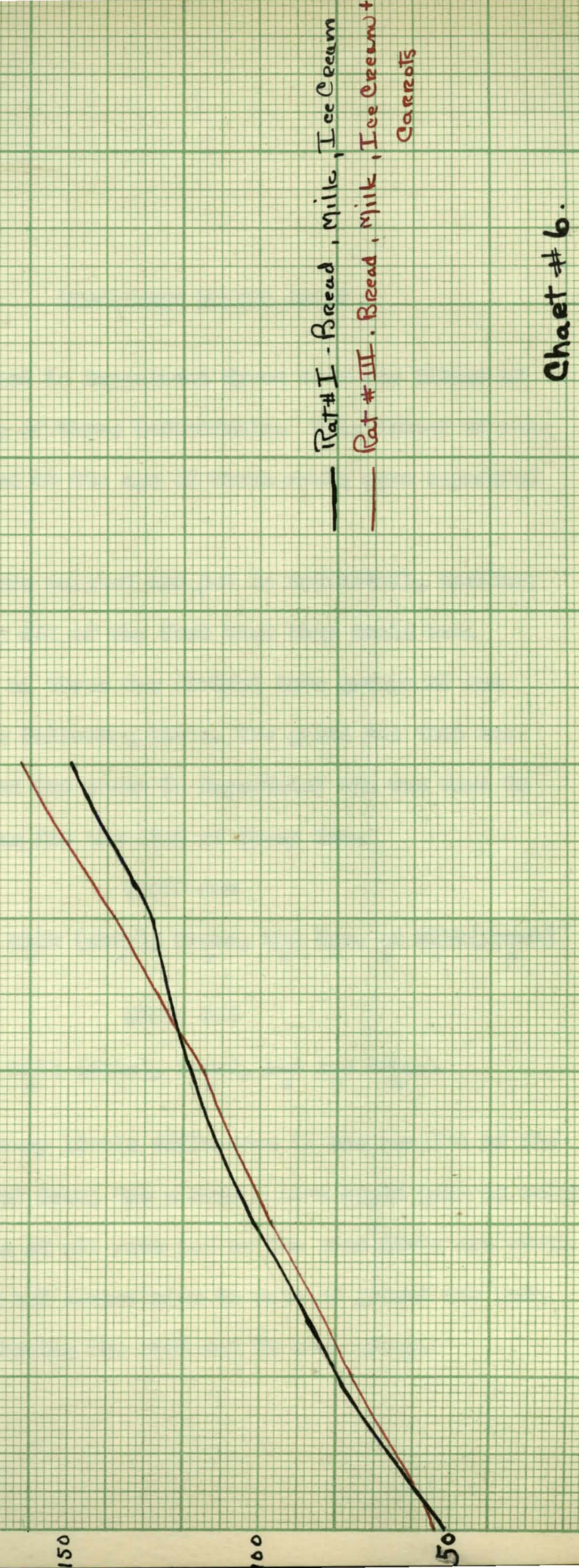


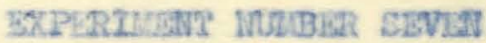

The rata used in Exporiment Seven were one litter of Albino lats consisting of three individunls. This litter of rats was bom Inareh 11th and at the ege of three weeks wore soyarated fron their nother.

The rats were velghed and put in individual, sanstary cages. Thoy were given all of the food that they could eat.

The litter of three was divided into groupo of one and two and fed on the following diots. The grown rat that was fed on bread, millk, and 200 croem in Ixperinent Sise was usod in this oxporiment and was fed the difot. of croup one.

\section{GROTP ONE}

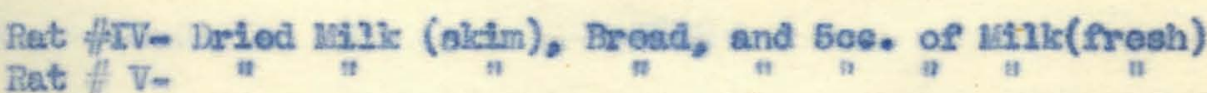

$$
\begin{aligned}
& \text { GROU. T:O }
\end{aligned}
$$

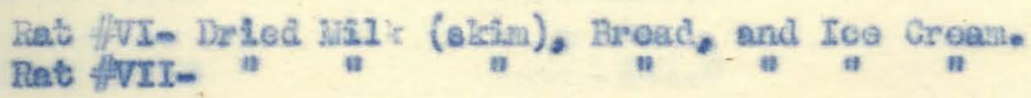

There was very 11ttle difference in the results of the two groups. The rats of Group one showed a vore raptd gain in weight. The wolghts of all rats fod on the same diets are given on the page following and comparisons in rate of growth are nade by moans of a chart shoving the bost rat in each group. 
GNOUP OAE (ZXPUILIMTAL).

\begin{tabular}{|c|c|c|c|}
\hline & & $\begin{array}{l}\text { Rat fIV } \\
\text { Iale }\end{array}$ & $\begin{array}{l}\text { Rat : IN } \\
\text { Male }\end{array}$ \\
\hline Apriz. & 4 & 41.5 gns. & 150.0 gase. \\
\hline " & 11 & 58.5 & 260.5 \\
\hline a & 18 & 78.5 & 178.0 \\
\hline " & 25 & 110.0 & 280.0 \\
\hline \multirow[t]{3}{*}{ llay } & 2 & 126.0 & 194.0 \\
\hline & & & GROUP Two (GRPRTLüMLAL). \\
\hline & & $\begin{array}{l}\text { Pat fivI } \\
\text { Fonale }\end{array}$ & $\begin{array}{l}\text { Rat WVII } \\
\text { Min.o }\end{array}$ \\
\hline Apri2 & 4 & 39.0 gne. & 41.0 gens. \\
\hline " & 11 & 60.8 & 6.0 \\
\hline : & 18 & 82.5 & 90.0 \\
\hline$"$ & 25 & 94.0 & 208.0 \\
\hline Iay & 2 & 107.0 & 131.0 \\
\hline
\end{tabular}




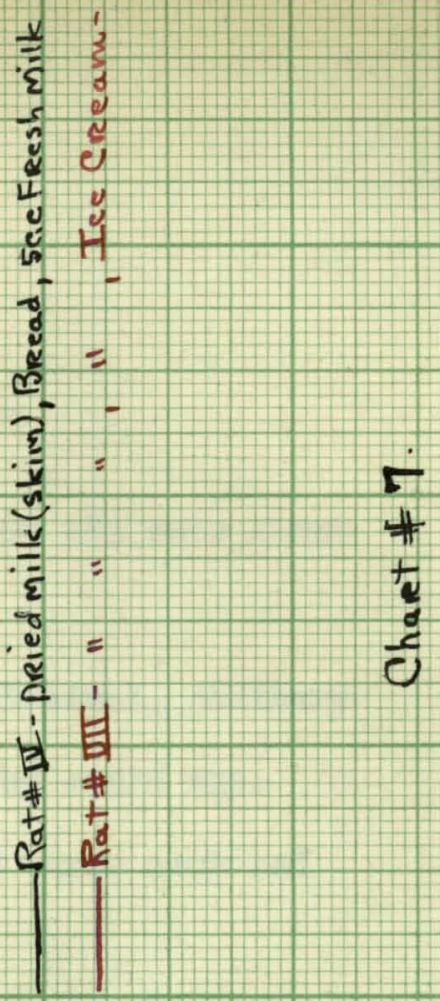

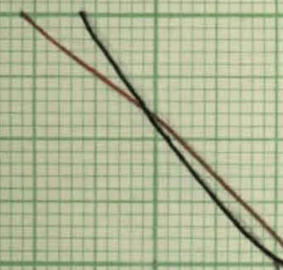

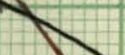


The rats used in Isperimont Bight wore six rats about two and ono-hale months old.

The rata wore woighod and put in Individual, santtary anges. They were. given all of the food that they could ent. They wore divided into two groups of three each and were fod on the rollowing aleta:

\section{GROUP OME}

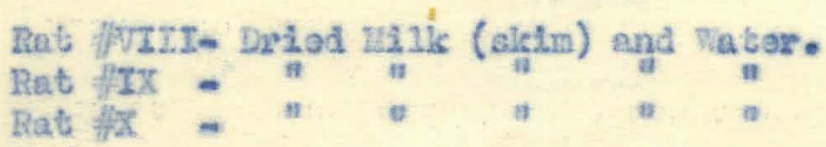

$$
\begin{aligned}
& \text { GROUL Tho }
\end{aligned}
$$

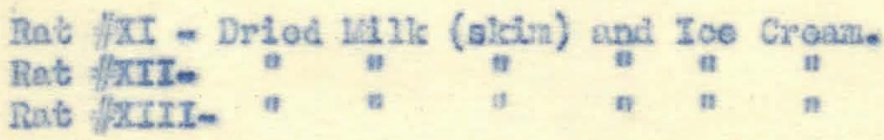

The rats fod in Group One showed a rapid loss in woight and the ones that Iivod developed ridcets at the ond of throe weoks. The rots of Group Tuo shoved a loss in weight, but thore wore no signa of richets. After throe woeks two of the tharee rats diod. The third rat was put on a rogular diot snd it galned veight rapiaty.

The dxiod rilik alono does not furnish enough of vitanins for growth and asintonance.

The welghts of sill mis fod on the sene diets aro givon on the go ge following and comparisons in rate of growith are made by moans of a chert showing the best rat in each group. 


\begin{tabular}{|c|c|c|c|c|}
\hline & & $\begin{array}{l}\text { Rat } \frac{a}{\pi} \text { VIII } \\
\text { Wele }\end{array}$ & $\begin{array}{l}\text { Rat } \| \mathrm{IX} \\
\text { Naze }\end{array}$ & $\begin{array}{l}\text { Rat in } \mathrm{x} \\
\text { Niale }\end{array}$ \\
\hline Apsil & 18 & 154.0 gms. & 193.0 gms. & 202.0 gns. \\
\hline$"$ & 25 & 151.5 & 145.0 & Died Apr. 20. \\
\hline Ilay & 2 & 110.0 & 111.0 & \\
\hline \multirow[t]{3}{*}{$"$} & 6 & Died & Died & \\
\hline & & \multicolumn{3}{|c|}{ GEOJP THO (BXFELIILITAL) } \\
\hline & & $\begin{array}{l}\text { Ract il XI } \\
\text { Fennale }\end{array}$ & $\begin{array}{l}\text { Rate } \frac{A}{71} \text { XII } \\
\text { Ilalo }\end{array}$ & $\begin{array}{l}\text { Rat H XIII } \\
\text { Female }\end{array}$ \\
\hline April & 18 & 153.0 gins. & 211.0 gas. & $131.5 \mathrm{~g}=\mathrm{s}$. \\
\hline a & 25 & 157.0 & 210.0 & 133.0 \\
\hline Nay & 2 & 144.3 & 170.5 & 121.0 \\
\hline$n$ & 9 & 133.5 & \multicolumn{2}{|c|}{ Died ley Gth. } \\
\hline
\end{tabular}



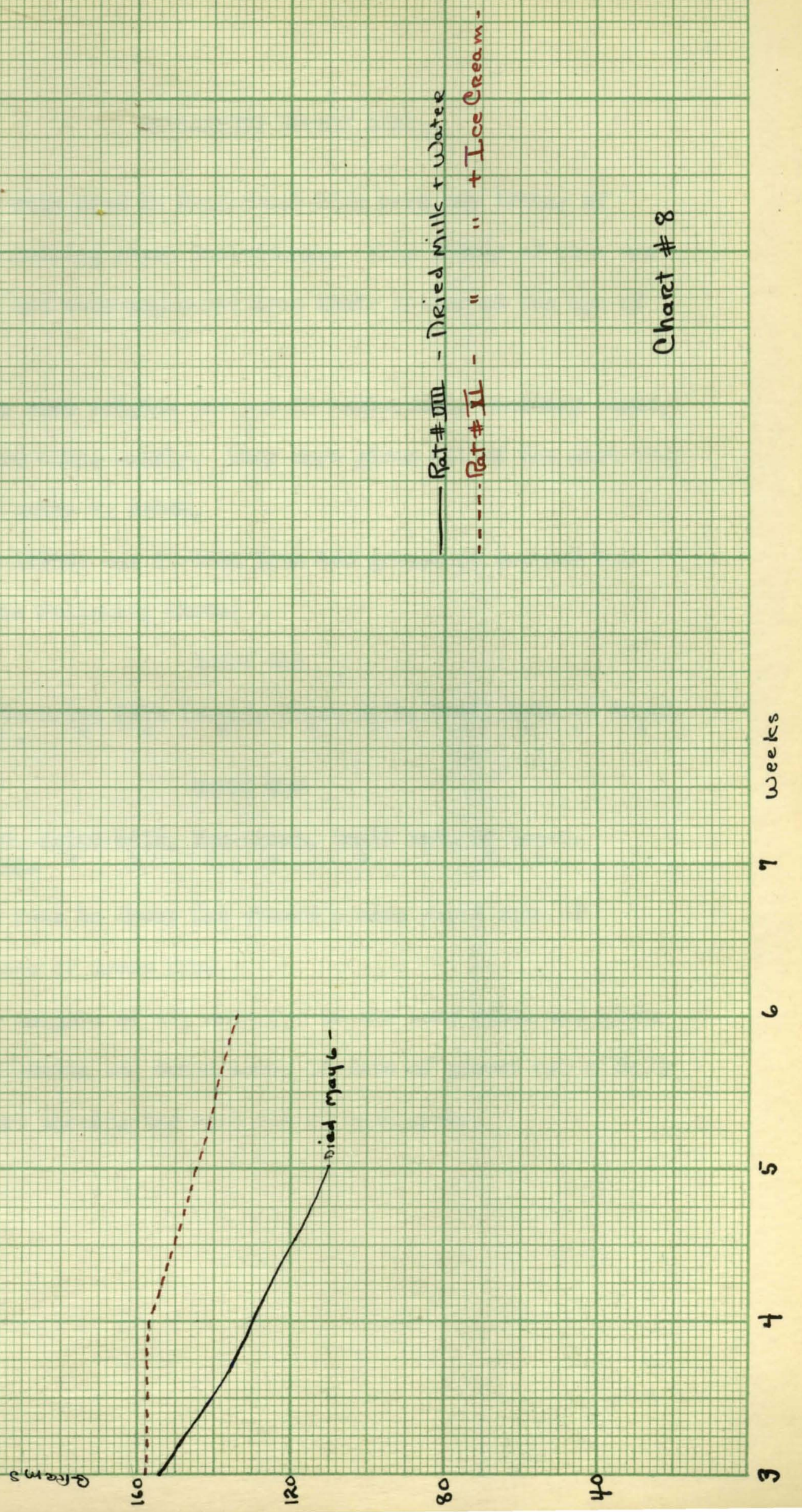
The rats bsed in Bxperimont wine wore one litter of Albino Rats contelniağ sevon individuals. This libter of retts vas Dorn April 3xd and were soparated from thelr nother at the age of three weolcs:

They ware weighed and put in individual, senitary cages, and wights were takon woekly. They were given ail of the diet they could eat also water to drink.

The littor wes divided Into two groups of two and two and wore Ped the following diets:

Grous otis

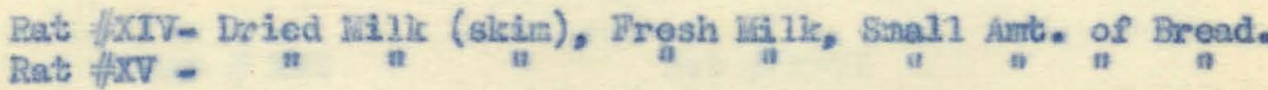

\section{GROUP T:0}

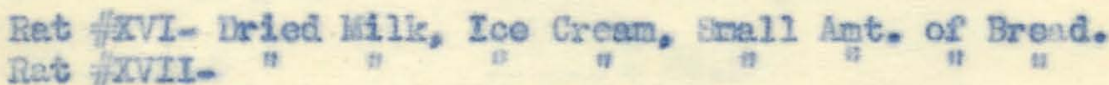

The rats in Group One showed a more rapid rete of Growth than those of Group Ino.

The weights of all rats fod on the sane diets are givon on the page following and cokperisons in rate of growth are ande by means of a chart ahowing the best rat of each group. 
GROUP OHS (EKPERTIBITAL)

\begin{tabular}{|c|c|c|c|}
\hline & & $\begin{array}{l}\text { Rat \# XIV } \\
\text { Ifale }\end{array}$ & $\begin{array}{l}\text { Rat \# XV } \\
\text { 1 Inlo }\end{array}$ \\
\hline April 25 & 25 & 42.0 ges. & 37.5 gns. \\
\hline Ning & 2 & 53.5 & 52.5 \\
\hline " & 9 & 60.5 & Died \\
\hline 26 & 26 & 53.8 & \\
\hline & & & GROUY TIO (EXPLRTIMUTAL) \\
\hline & & $\begin{array}{l}\text { Rint \# XVI } \\
\text { Jalo }\end{array}$ & $\begin{array}{l}\text { Rat 류 XVII } \\
\text { Ponalo }\end{array}$ \\
\hline April 2e & 25 & 32.0 gus. & 37.5 हुง. \\
\hline Hay & 2 & 40,0 & 38.5 \\
\hline & 9 & 55.5 & Died Iay 6th \\
\hline & 16 & 56.5 & \\
\hline
\end{tabular}




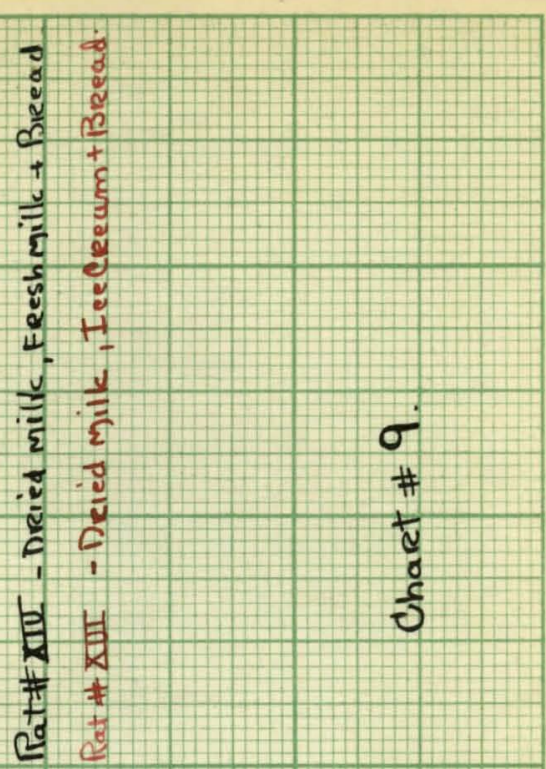

surady

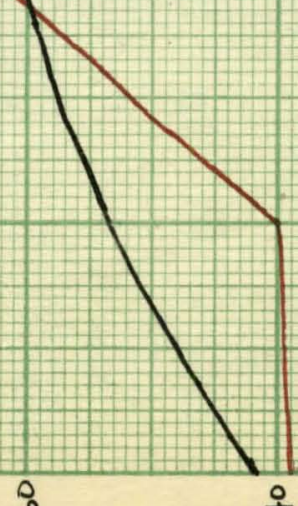



The Influence of a high and low vitunin content in the diet is show in the following ways:

1. The rabs fod on a dot bigh in Vitanin $A$ and $B$, showod a more rapid rate of grouth than those fed on a diet low in vitanin $A$ and $B$. The fur of the rate jed on a diet bigh in Vitamin $A$ and $B$ was of unusual whiteness.

2. Tho rata fod on a difot high in Vitamin $A$ and $B$ shosod a olow but continued increese in woight over the rats fed on a diet low In Vitamin B. The fur of the ratg fod on a diet low in vitanin B became yelllow and atringy.

3. The rats for on a difot $\mathrm{htgh}$ in vitamin A and B oxe h2bited unusul healthy, nornal activity. Fhelix fur vas very soft and white. The rats fod on a di.ot $1 \mathrm{cw}$ in VItamin $\mathrm{A}$ showed a vory dow gain in woikght.

4. The rats $\mathrm{fed}$ on $\mathrm{a}$ dijet high in Vitamin $\mathrm{A}$ and $\mathrm{B}$ vore perfootly hoalthy and cleveloped a long cont of fur of unuatual whitenoes. The rats fod on a diet low in Vitamin A mede only a slight Inoroase in weight. Theîr fur turned dnrk and bristly.

5. The rats fed on a diet high in Viternin $A$ and B woro very active and showed a rapid gain in weight. Those fod on a diot low in Vitanin $A$ and $B$ were vory 1 istiess, inective and mede a alow gain in weight. 
6. The results obtalned on the diets of Bread, 1/i.1t, and

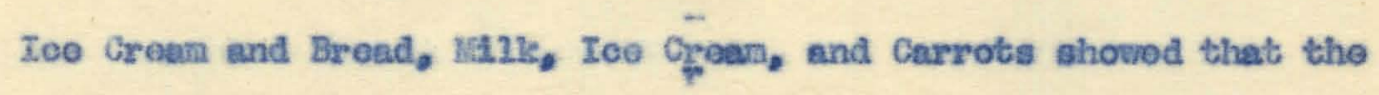

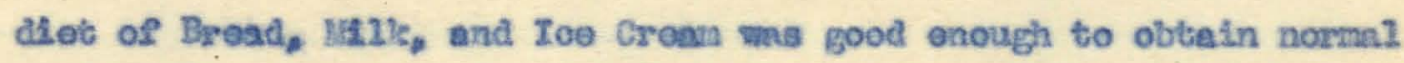
resulta.

7. The rats sed on a diot high in Vttrenin A made sane incrouse in welght over the rats fod on a difot alightly lowor in Vitanin A.

8. The rats ged on a diot Ior in Vtamin A and D lost repidiy in veight nat the onos that lived dovelopod rielsots. Tho - rats fod on a diot a 11 btio higher in Vitomin A and D lost woight but did not levelop rietrots.

9. The rates fod on a di.st high In vitamin A and B had ua nore rapid rate of growth than tinose fod on a diet zow in Vatamin A. In all eases whore frosh milte was supplied in the alot, the rate of grtwith was more raptd. Fron all the exporsmonts triod the difot wisth proved most satiafnetory sas thet of Broad, Malk, and toe Crean in which thore wes a high pitamin content. 


\section{REFERUCES.}

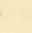


QUANTITATIVE ASPEGTS OF ROLE OF VITANIN B. IN WURTITION. by T. B. Osborne and L. B. Ilondel. Journal of Biological Chenistry, Vol. 54, R. 739-52, 1922 .

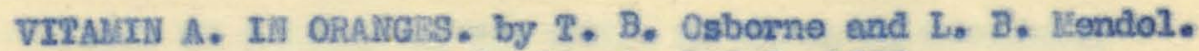
Proc. So0. Expt1. Biol. Nied, Vol. 19, P. 187-8, 1922.

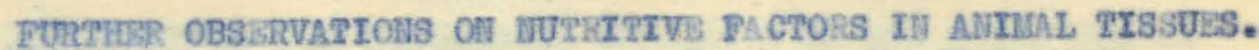
by T. B. Osborne and L. B. Nendel, Proc. Soo. Ixxptl. Blol. Nod. Vol. 15, P. 71-2, 1918 .

PRE: T. B. Osborne and L. B. Nondel, Journel of 3iologicel Chenistry, Vol. $39, P$. $39-46,1919$.

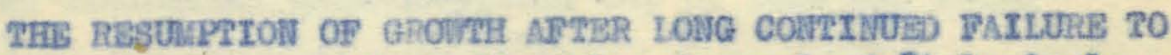
Groil. by T. B. Oalorne and L. B. Llondel, Journal of Biological Chentstry, Vol. 23, ${ }^{2} .439-54,1915$, .

THE BHFtCI

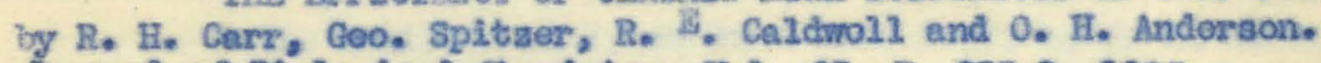
Journal of Biologicel Chomiatry, Vol. 63, P. 235-8, 1925.

THE ROLE OF VTTAITI B. III RILATTON TO SIZS OF GROMING RATS. by 9. B. Osborne and L. B. Liendel. Journel of Biological Chemistry. Vol. 68 , P. 501-9, 1917 .

CHECKTNG OF GROUTH AMD DEVELOINEMT OF RATS FED OII A

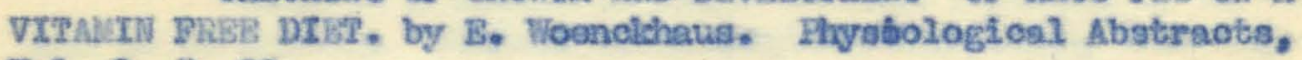
Vol. 8, P. 23.

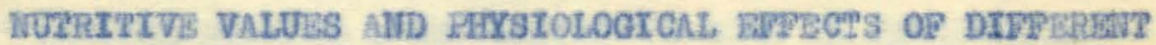
OTLS AND FATS. byJ. F. Moclure and R. E. Carr. Americean Journal. of Ityyaiology. Vol. 74, P. 70-8, 1925.

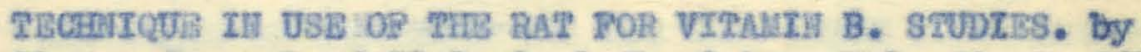
E. V. MoCollum, Journal of Btologteal Chontstry, Vol. 63, P. 547-51, 1925.

BUTCHER STUDLSS OP THE CAUSE OF ORHTHALIA II RATS ERO

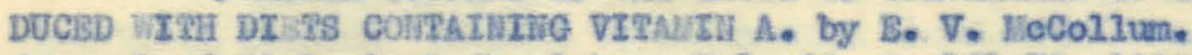
Journal of Blologionl Chomiatry, Vol. 64, P. 161-79, 1925.

IHFLUITCS OF DTET ON TE ME AND BONIS, by Gutton Toverud. Journal of BLo2. Chemistry. Vo2.58, P. 583. 1923. 
STUDIES OF VITAINE POTEICY OF COD IIVER OIL. by A.D.Finlmes, Industrial and Engineoring Chemistry, Vol.16, P. 379 30, 1924.

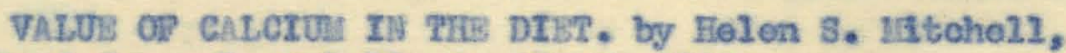
Amerticen Food Journal, Vol.18, P. 463-5, 1923.

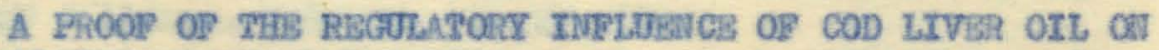
GnLCTUI AmD PHOSPIOROUS MEPABOLISI. by E.A.Park, Ruth Guy, and G.P.Poworb. Amorican Journal of Diseases of Children, Vol. 26, B. $103-111,1923$.

PRODUCTION ON RTCKETS IN RAFS BY DTETS COUSISTIHC OP PORIFIED FOOD SUBSTAHCES. by E. V. HoCollum and HLina Sînenonde. Journal of Blological Cheniatry, Vol. 54, F. 249-52, 1922.

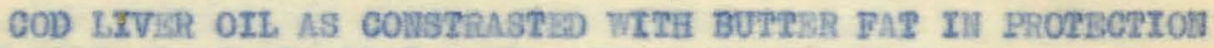
AGUIUST THE IFTECTS OF INSUEDICISHT CALCTUE IN THE DIET. by E. V. NoCollum, Proc, Soc, Expt1. Biol. Iled, Vol, 18, P. 275-7 1921.

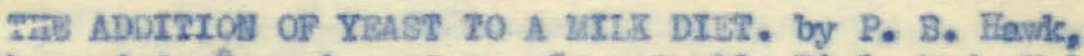
C. A, Smith, and O. sBorgolm. Broe. Soe. Bxptl. Blol. Mod. Vol. 18, P. 168 , 1021 .

OEFTHAW TA AND DIET. Joy T. B. Osborne and Le B. Hendel, Journal of Amerioan Ladtanl Association. Vol. 76, P. 905-8, 1921.

IIIJ AS A SOURG OP WATER SOLUBIB VISAMIN. by T. B. Osbome and L. B. Itondol. Journal of Blologicel Cheniotry, Vol. 41 , P. $525-23,2920$,

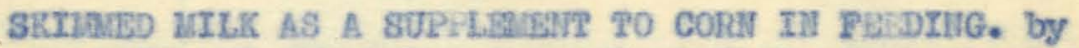
T. B. Osborne and Is B. Ilondel. Journel of Blological Chemistry, Vol. 44, P. 1 - 4, 1920.

TMLUSHCE OF COD LTVER OTL AMD SOIB OTHIA FATS ON GROWPI. by T. B. Osborne and L. B. Flondol. Journal of Biological Chemiatry, Vol. 17, P. $401-8,1220$.

TWLUMICE OF BUTPBR DAT OH GRONH. by T. B. Osborne and L. B. Jendel. Journal of Blologteal Chomistry. Vol.16, P.423-37.

THE IFPECT OF DIET ON THE COUTMAT OF VITAMIII B. III LIVAR. by T. B. Osborne and L. B. llendel, Journal of Blologleal Chemistry, Vol. 58, P. 369- 71, 1922 . 


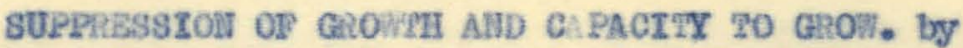
T. B. Osborne and L. B llesdel. Journal of Blologiesd Chemistry. Vo1. 18., 1914.

ULTRAVIOLET RADTARIOU III RICKEPS. Ameriean Journal of DAseasos of ChIlAren, Vol. 24., 2. 20, 192\%.

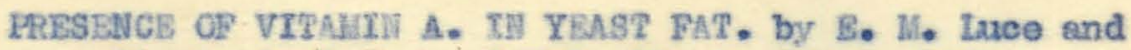
I. S. Iaclean. Bioohentcel Journal.Vol. 19, P. 49-51, 1925.

QUANTITATIVE DEREHImATION OF VITANIN A. by H. C. Sherman and I. E. Hunsell. Journal of Anorican Chemicel Socloty, Vol.47, B. 26 s9-46, 1925.

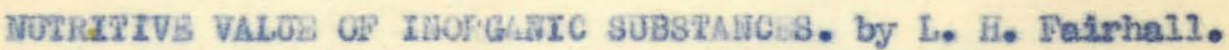
Journal of Eiological Chemiabry $\nabla 02.70$, P. 495-512, 1926.

RRODUCTIOH OF GAGIIIS AND SIIILAR DISBASES IN RATS BX DIFFEREIT DLEPS. by B. V. FeCollun and Hina Simmonds. Journal of Biological Chenistry. Vol. 45, פ. 358-42, 1921.

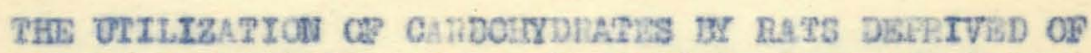
VITAMrN B. by F. A. Latstil. Journal of Biologicel Chomistry, Vol. 55, P. $73.7-27,2825$.

A PRELITIMARY STUDY OF GLOSS RAXTLLARY AMD DEMTAL DIPSCTS

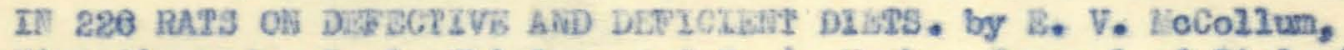
Ilina Simmondis, F. E. Shipley, and B. As Park. Journal of Biologicell Chemistry. V01.47, P. 509-27, 1923.

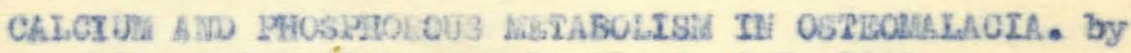
Journal of Experimental Nedíeino, Vol. 41, P. 187, 1925. 